昭和大学の体系的, 段階的なチーム医療教育カリキュラム

木内祐二十

\title{
Systematic and Stepwise Interprofessional Education in Showa University
}

\author{
Yuji Kiuchi ${ }^{\dagger}$ \\ Department of Pharmaceutical Education, School of Pharmacy, Showa University; \\ 1-5-8 Hatanodai, Shinagawa-ku, Tokyo 142-8555, Japan.
}

(Received January 9, 2017)

\begin{abstract}
At Showa University, which consists of the schools of medicine, dentistry, pharmacy, nursing and rehabilitation sciences, systematic interprofessional education was introduced with the cooperation of all 4 schools and through all undergraduate grades with the purpose of training medical staff who can contribute positively to the medical team. In the lower grades, students study the basics of medical team care based on a 4-school joint curriculum of experience learning (such as early exposure) and problem-based learning (PBL) tutorial inside and outside of the university. In the upper grades, students study the practice of medical team care by joint curriculum of participatory learning in the hospitals and community so as to acquire practical skills. Since 2014, we introduced systematic interprofessional education for home care and narrative-based medicine. Through these curriculums, I expect that the number of medical staff who actively promote patient-centered team medical care in a variety of medical fields, including hospitals and community, will continue to grow in the future.
\end{abstract}

Key words — interprofessional education; curriculum; problem-based learning tutorial; team medical care; narrativebased medicine

\section{1. はじめに}

現代の医療では，多くの職種が連携・協調し，情 報の共有と十分な討議により患者中心の最善の医療 を協力して実施するチーム医療が求められている. 在宅医療から高度医療まで多職種連携が前提の医療 も多く, 情報共有の不足による医療ミ久, 医師不 足・偏在などの課題の解決にもチーム医療の実践が 望まれている. ${ }^{1)}$ 一方で, 従来の医療系大学教育で は，各学部の専門性に特化した教育が中心で，チー 厶医療学習は積極的には実施されていなかったが, こうした社会のニーズに応えるべく，大学教育も新 たな改革のステップを迎えようとしている。薬学教 育のモデル・コアカリキュラムの改訂版2)において も卒業時までに修得すべき「基本的資質」（コンピ

昭和大学薬学部薬学教育学（テ142-8555 東京都品川区 旗の台 1-5-8)

現所属: ‘昭和大学医学部薬理学講座医科薬理学部門

(下142-8555 東京都品川区旗の台 1-5-8)

e-mail: ykiuchi@med.showa-u.ac.jp

本総説は, 日本薬学会第 136 年会シンポジウム $\mathrm{S} 03$ で 発表した内容を中心に記述したものである.
テンシー）のなかに，「チーム医療」が明記され， 現在, 大学毎に特徵あるチーム医療教育の取り組み が試みられている，以下に，大学における多職種連 携教育（interprofessional education; IPE）のあり 方を検討する一助となることを期待し，チーム医療 の学習に積極的に取り組んでいる昭和大学の例を紹 介する.

\section{2. 昭和大学の特色}

昭和大学は, 医学部, 歯学部, 薬学部, 保健医療 学部（看護学科, 理学療法学科, 作業療法学科) か らなる医系総合大学（1学年約 600 人）であり, 「学部の枠を越えてともに学び，互いに理解し合 え, 協力できる人材を育成する」ことを大学の教育 理念に明記し，チーム医療に積極的に貢献できる人 材養成を全学部に共通する教育の目的としている.

1 年次は山梨県富士吉田市で 4 学部の全学生が全 寮制教育を受け (寮は学部混合の 4 人部屋), 2 年 次以降は東京都品川区の旗の台校舎で, 医・歯・薬 学部と大学病院が併置された環境で学習し, 各学部 の学生, 教員の交流が日常的である. また, 附属 8 


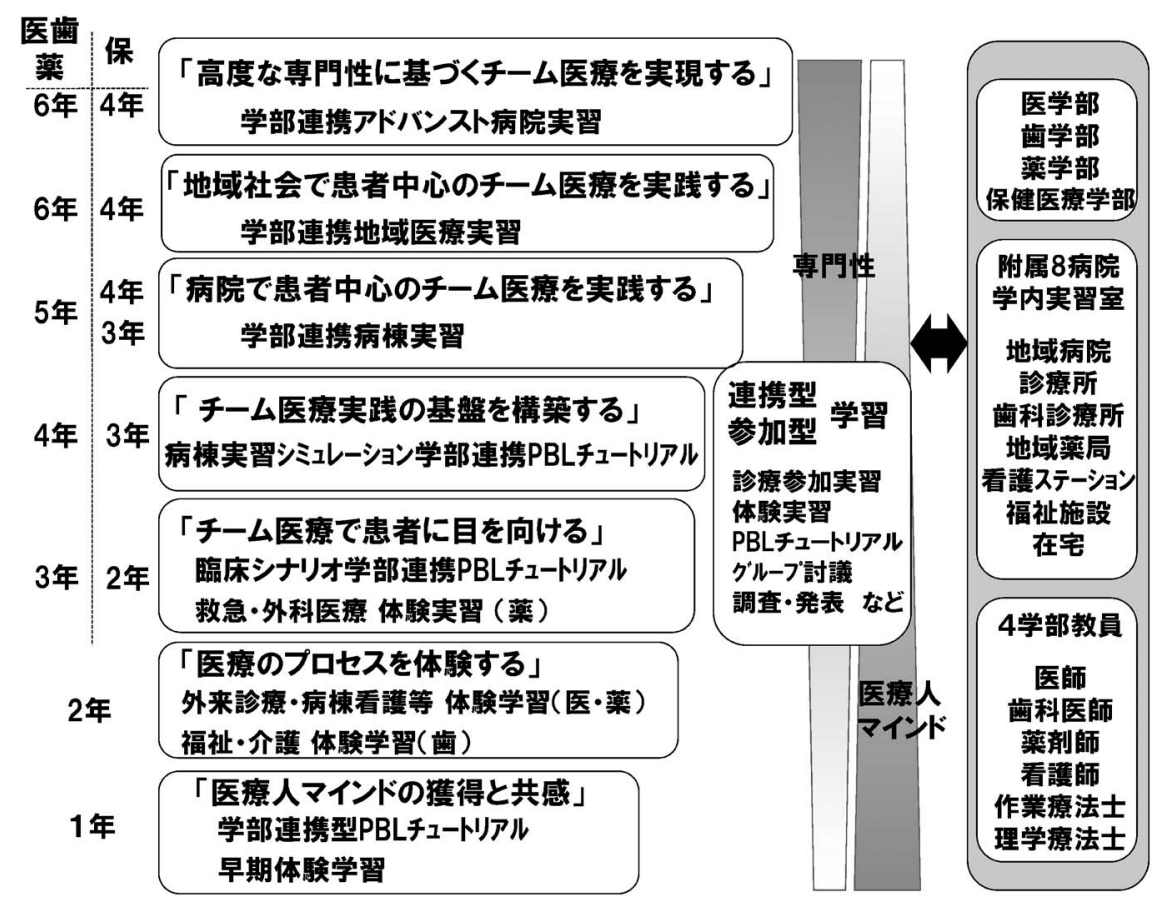

Fig. 1. Systematic and Stepwise Interprofessional Education at Showa University

病院（約 3200 床）で多彩な臨床実習と各学部の学 生受入れができるという特色を持つ。こうした学習 環境を活かし，チーム医療の実践に必要な多様な能 力の修得を目的に, 様々なチーム医療学習カリキュ ラムを導入している.

\section{3. 体系的・段階的なチーム医療学習}

大学の教育理念を具現化するため, 平成 18 年度 から，文部科学省の支援を受け，全学年にわたる学 部連携教育カリキュラムを構築した。 学年に従って 体系的, 段階的に学習の場と内容を広げ, 確実に チーム医療に必要な能力を修得する学習となるよう に工夫している，すなわち，低学年では，チーム医 療の基盤作りとして，大学内外での体験実習や problem-based learning (PBL) チュートリアルな ぞの問題解決型学習, 高学年では, 大学病院や地域 社会での実践的なチーム医療学習を，いずれも原則 的に 4 学部合同カリキュラムとして実施している (Fig. 1).

3-1. 学部合同早期体験実習 1 年次の全寮制 の環境を活かした必修の実習として，9 日間にわた る体験実習を行っている。４学部合同の学生グルー プで, (1)病院見学 (1 日, 病院の各部署の見学),

(2)福祉施設体験（3 日，施設利用者に対するサポー 卜の体験), (3)AED+心肺蘇生（半日）及び外科的
救急処置（半日）の実習を行い，さらに，各学部独 自の体験実習も 3 日間実施している。最終日には, 学部合同グループによる発表と討議を行う。病院は 約 10 力所, 福祉施設は約 40 力所という大きな規 模・内容となっているが，チーム医療の実際を見聞 し, その重要性を学ぶとともに, 学習に対するモチ ベーション付けに有用な実習となっている.

3-2. 医療・福祉におけるチーム医療のプロセス の見学学習医・歯・薬学部の $2 \cdot 3$ 年次では, 各学部がそれぞれ, 学内外の医療・福祉の現場で, 多職種が協力した医療・福祉のプロセスと連携の実 際を，見学を通して学習する。薬学部では，2 年次 「診療の流れを知る」で, 大学病院の看護見学, 病 院・診療所の医師の外来診療見学, 病院薬剂師業務 見学を行う. 3 年次「救急医療・外科医療と薬剂師」 では, 大学附属病院の手術部, 救命救急センターで 体験学習を行う。このような実習を通して, チーム 医療・福祉のプロセスを多面的に学習できるように 工夫している.

3-3. PBL チュートリアルによる問題解決型学習 PBL チュートリアルでは, 臨床推論（問題点抽 出), 患者の問題解決, 統合的学習 - 知識の総合, 自学自習, 能動的学習, 医療コミュニケーションな ぞの能力の修得が期待され, チーム医療・患者中心 
の医療の学習に有用である.

昭和大学では, チーム医療学習を目的に 4 学部連 携型の PBL チュートリアルを $1 \cdot 3 \cdot 4$ 年次（保健 医療学部は $1 \cdot 2 \cdot 3$ 年次）に実施している. 1 年次 では，チーム内のコミュニケーションや情報共有に 慣れるとともに, 自学自習の習慣づけのための入門 用 PBL と位置づけ，学年が進むに従い，実際の医 療を想定し，患者が抱える問題を推論し，最善の問 題解決を求める学習としている.

1 年次には, 福祉・介護, 終末期医療, 寮生活, 栄養・健康に関する話題などを基にしたシナリオ で，富士吉田校舎で 1 年間に 3 回 $\times 3$ 週（コアタイ ム 2 回十発表会）のPBL チュートリアルを実施し ている. 3 年次（保健医療学部は 2 年次）「臨床シ ナリオ学部連携 PBL チュートリアル」では，ある 程度複雑で全学部学生が関心を持つ臨床症例を基に したシナリオやビデオを用意し， 1 回 $\times 3$ 週（コア 夕イム 2 日十発表会 1 日）実施している。 3 年次で は，各職種の視点で患者症例を解析し，他学部の学 生にもわかり易く説明し，全員で患者の多様な問題 点を抽出して治療やケアについて提案を行う積極的 な取り組みが認められ，チーム医療学習における PBL チュートリアルの有用性を実感することがで きる. 4 年次（保健医療学部は 3 年次）「病棟実習 シミュレーションPBL チュートリアル」も，1 回 $\times 3$ 週で実施するが，診療録，看護記録などの病棟 で用いられている書式で入院患者を提示し，入院後 の問題をこれらの資料から抽出することから取り組 み, 小グループ討議でチーム医療による最善の治療 やケアをまとめる.

1 学年の 4 学部生 600 人を学部混合の 70 前後の グループに分けて，学部連携型 PBL チュートリア ルを実施するには，学習環境の整備（PBL ルーム や電子ポートフォリオシステムなど）とともに，全 学部学生が関心を持つシナリオの作成と, 標準的な 指導を行う教員（ファシリテーター）の養成が必要 である。学部連携型 PBL チュートリアルには，こ うした準備と円滑な運営にかなりの手間を要する が，この学習により，チーム医療の有用性を学生自 身が実感するとともに，病棟でのチーム医療実践の ためのシミュレーションにもなっている.

3-4. 学部連携病棟実習昭和大学では医. 歯・薬学部 5 年生, 保健医療学部 $3 \cdot 4$ 年生は全員
が附属病院で長期実習を実施している。この実習期 間を利用して，医・歯・薬学部 5 年生，保健医療学 部看護学科・作業療法学科 4 年生, 理学療法学科 3 年生の学部合同チーム (4-6 人程度, 約 120 チーム) による 1 週間の学部連携病棟実習を必修で実施して いる. 実施病棟は附属 7 病院の約 40 病棟で， 120 チームの実習を行うために $7 \cdot 9 \cdot 10$ 月の 3 期に分 けて実施する，実習では，同じ患者を学部合同チー ムが連携, 協力しながら担当し, 毎夕にミーティン グをして，患者情報の共有と治療・ケアについて討 議, 提案するとともに, 他学部の学生の活動を見学 することで相互理解を深める実習である．実習の指 導や評価のために，4学部から指導担当教員を各 チームに派遣し, 多職種の病棟スタッフとともに学 生の支援を行っている.

円滑な実習の実施のために，事前に各病棟のス タッフ (医師，歯科医師，薬剂師，看護師，リハビ リ技師）や指導担当教員を集め，ワークショップ形 式で詳細なスケジュール作成と指導方法の説明を 行っている.

医学部生は診断や外科治療, 薬学生は薬物治療, 歯学部生は口腔ケア, 看護学生は患者心理・介護 QOL, 理学・作業療法学生はリハビリテーション や activities of daily living（ADL）の視点から，患 者の多くの情報を収集・検討し，それぞれの学部実 習では気付くことのない幅広い視点から討議を行 い，入院中から退院後までにわたる多彩な治療やケ アを提案している。 また，他学部の学生の実習や業 務を見学することで，相互の職能に対する理解が深 まる. 1 年生から各種の学部連携実習を経験した学 生であるためか，すぐに打ち解けて楽しげにコミュ ニケーションし，患者の問題点を図（プロブレム マップ）にまとめ，積極的に討議や発表を行ってい ることが印象的であった。

3-5. 学部連携地域医療実習選択実習とし $\tau$, 最終学年の医・歯・薬学部 6 年生, 保健医療学 部 4 年生を対象に，在宅医療をチームで実施してい る地域で，学部連携地域医療実習（2 週間）を実施 している．診療所，歯科診療所，薬局，訪問看護又 テーションなどの連携の取れた地域で，在宅患者を 学生チームが担当する．在宅医療を各専門職の立場 から理解し, 最善の医療・介護を医療チームとして 討議し提案するとともに，在宅医療に係わる様々な 


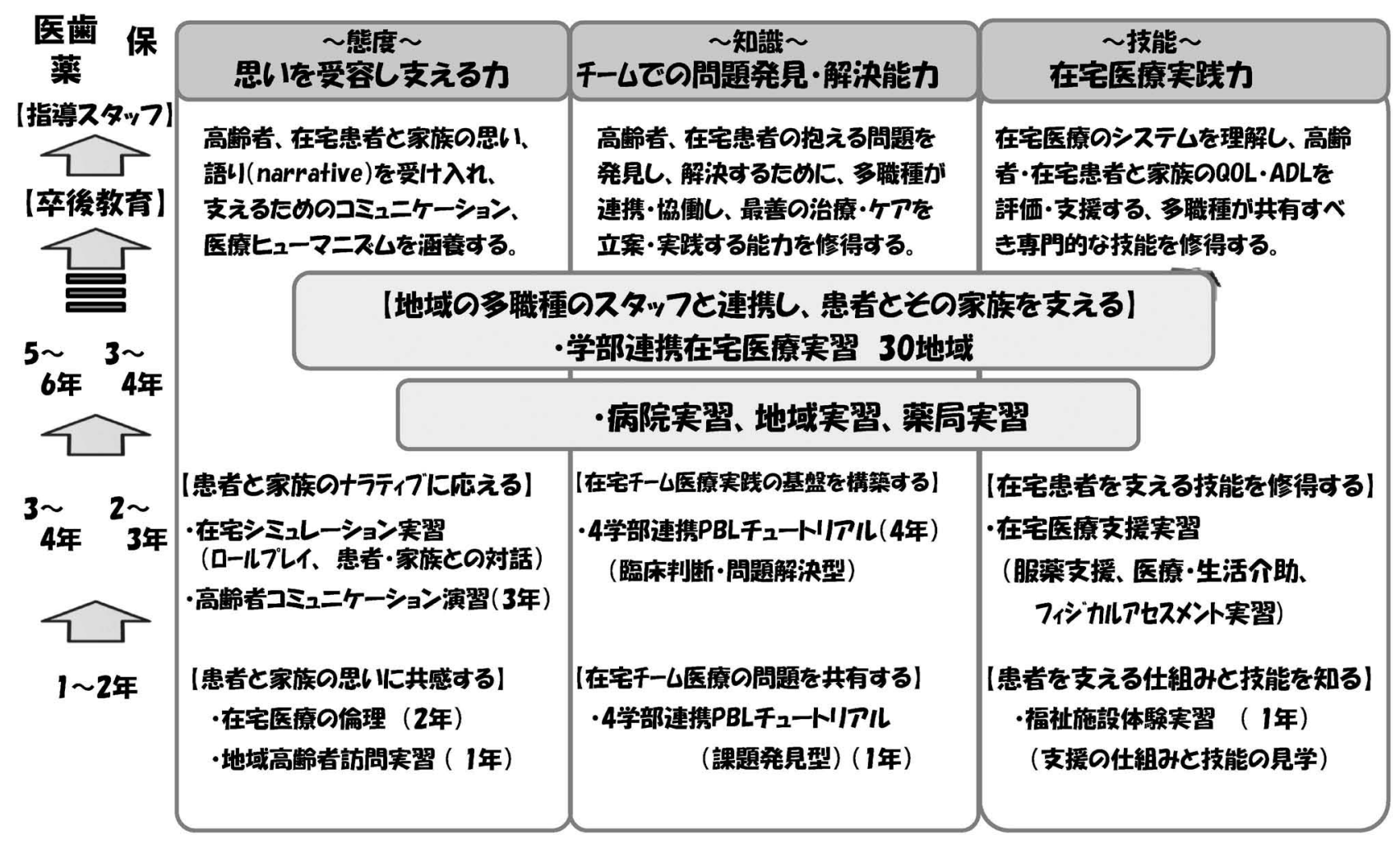

Fig. 2. Systematic Interprofessional Education for Home Care in the Community at Showa University

専門職の役割を相互に理解することを目的とした害 習である.

現在のところ，東京都内，神奈川県内と山梨県富 士吉田市の 6 地域で実施している。それぞれに 10 程度の医療・福祉施設が加わり，各施設の見学と在 宅医療への参加を組み合わせた手間のかかる実習で あるが，事前に綿密に作成された各学部生のスケ ジュールに従って，円滑に実習が実施されている. 難治神経疾患や認知症などの患者を担当し, 数回, 担当患者宅を訪問するが，それ以外にも医療スタッ フと 10-20 名の在宅患者宅への訪問に同行する。ほ ぼ毎日，学生グループは診療所の医師を交えてミー ティングを行い, 担当患者の病態, 治療やケアにつ いて討議し, 最終日には, 実習のまとめを発表す る. 学生は在宅患者に対するチーム医療の重要性と ともに, 地域医療における多職種連携と患者情報の 共有の難しさについても実感し，こうした課題解決 のための提案を行うグループも多い.

4. 在宅チーム医療教育の新たな取り組み

高齢化が進む日本では，医療の場が病院から地域 さらに在宅へと拡充しつつある。在宅医療において も，地域の多職種が連携・協力しながら，患者の
QOL の向上あるいは維持のために適切な治療とケ アを積極的に実践する「在宅チーム医療」が求めら れており，それが「地域包括ケアシステム」の基盤 となると期待されている.

昭和大学では，こうした在宅チーム医療を積極的 に実践する医療人の養成を目的に, 文部科学省の課 題解決型高度医療人材養成プログラム「在宅チーム 医療教育推進プロジェクト」（平成 26-30 年度）の 支援の下，学内外で 4 学部が連携する体系的な在宅 チーム医療教育カリキュラムの構築に取り組んでい る. カリキュラムは「思い（ナラティブ）を受容し 支える力 (態度)」「チームでの問題発見・解決能力 (知識)」「在宅医療実践力 (技能)」を 3 つの柱とし て，全学年で学部連携型のカリキュラムを実施する 予定である. 既に平成 27 年度の 1-2 年次では, 「地 域高齢者訪問実習」「4 学部連携 PBL チュートリア ル（課題発見型）」「福祉施設体験実習」「在宅医療 を支える NBM と倫理」(narrative-based medicine; NBM）を実施した。「地域高齢者訪問実習」では, 富士吉田市内の約 60 名の高齢者のご協力を得て, 1 年次の 4 学部合同グループが, 高齢者宅を訪問して 数時間歓談し, 日常の生活や健康状態などについて 
お話を伺い，高齢者のナラティブを聞き取る実習を 行った. 1 年次の「4 学部連携 PBL チュートリア ル (課題発見型) 」, 2 年次の「在宅医療を支える $\mathrm{NBM}$ と倫理」では，独居の高齢女性（認知症）と その家族に関するビデオを作成し, 学部合同 PBL チュートリアルで，ビデオを題材に高齢者のナラ ティブを支える家族のあり方についてグループ討議 を行った。

さらに, 3-4 年次では「高齢者コミュニケーショ ン演習」「在宅医療支援実習」「4 学部連携 PBL チュートリアル（臨床判断・問題解決型）」「在宅シ ミュレーション実習」を平成 29 年度以降, 順次実 施する予定である．6 年次には，前述した「学部連 携在宅医療実習」を拡充し, 約 30 地域で実施する 計画で，準備を進めている（Fig. 2).

昭和大学では，上述したような体系的，段階的な チーム医療教育カリキュラムにより, 病院や地域で チーム医療を円滑, 効果的に実践できる医療者の養
成に積極的に取り組んでいる。こうした昭和大学の 取り組みが，さらに改善を加えながら全国のチーム 医療学習のモデルの 1 つとなることを期待したい.

利益相反 開示すべき利益相反はない.

\section{REFERENCES}

1) Ministry of Health, Labour and Welfare, "Promotion of team medical care, Report of study group on promotion of team medical care.": 〈http://www.mhlw.go.jp/shingi/2010 /03/dl/s0319-9a.pdf\#search $\rangle$, cited 16 February, 2017.

2) Ministry of Education, Culture, Sports, Science and Technology. "Model Core Curriculum for Pharmaceutical Education-2013 Revised edition-": 〈http://www.mext.go. jp/a_menu/01_d/08091815.htm $\rangle$, cited 16 February, 2017. 